\title{
REPRODUCTIVE BIOLOGY OF A CHARACIDIINAE (OSTEICHTHYES, CHARACIDAE) FROM THE UBATIBA RIVER, MARICÁ - RJ
}

\author{
MAZZONI, R., ${ }^{1}$ CARAMASCHI, E. P. ${ }^{2}$ and FENERICH-VERANI, N. ${ }^{3}$ \\ ${ }^{1}$ Universidade do Estado do Rio de Janeiro, Instituto de Biologia Roberto Alcântara Gomes/Ecologia, \\ Rua São Francisco Xavier, 524, Maracanã, CEP 20550-013, Rio de Janeiro, RJ, Brazil \\ ${ }^{2}$ Universidade Federal do Rio de Janeiro, Instituto de Biologia, Departamento de Ecologia, \\ CEP 68020, Rio de Janeiro, RJ, Brazil \\ ${ }^{3}$ Universidade Federal de São Carlos, Centro de Ciências Biológicas e da Saúde, Departamento de \\ Hidrobiologia, Via Washington Luís, km 235, CEP 13565-905, São Carlos, SP, Brazil \\ Correspondence to: Rosana Mazzoni, Universidade do Estado do Rio de Janeiro, Instituto de Biologia Roberto \\ Alcântara Gomes/Ecologia, Rua São Francisco Xavier, 524, Maracanã, CEP 20550-013, Rio de Janeiro, RJ, Brazil, \\ e-mail: mazzoni@uerj.br \\ Received June 6, 2001 - Accepted October 8, 2001 - Distributed August 31, 2002
}

(With 5 figures)

\begin{abstract}
The Ubatiba river is a coastal stream subject to stochastic spates all over the year and, Characidium sp.n. is among the twenty-two species that compose its ichthyofauna. In this study we analyse some traits of its reproductive biology and discuss whether the adopted strategy has causal relationship with the environmental variables. Specimens were collected in the upper Ubatiba river. Samplings, were carried out monthly by electrofishing, between Oct./94 and Sep./95. Some differences between male and female strategies were observed. Females were significantly $(p<0.05)$ bigger than males; length weight relationship was different $(\mathrm{p}<0.05)$ between sexes with the onset of sexual maturity occuring at smaller sizes among males. Reproductive investment is high for both males and females but higher for males, maximum Gonadosomatic Index for females and males were $40.97 \%$ and $44.90 \%$, respectively. Reproductive specimens were registered all over the year, suggesting continuous reproduction. High values of fecundity were also registered varying from 1342 to 5535 eggs for ripe females of 4.4 and $7.0 \mathrm{~cm}$, respectively and an amount of 1105 oocytes per grams of fish. We suggest that differences in the reproductive strategy, between sexes, determine the observed patterns in the size structure; the absence of males in the higher SL classes could be a consequence of high mortality rates and/or reduction in the growth rates as a precocity consequence in the onset of reproduction and/or high reproductive investment. Relationship between continuous reproduction and environmental condition could be explained as an adaptation to maximise supervivency of the young fishes that is: guarantee the species maintenance in a stochastic environment.
\end{abstract}

Key words: Characidiinae, coastal stream, reproductive biology.

\section{RESUMO}

\section{Reprodução de peixes em riacho costeiro}

O rio Ubatiba é um riacho costeiro sujeito a chuvas torrenciais imprevisíveis e Characidium sp.n. é uma das 22 espécies que compõem sua ictiofauna. Neste estudo, são analisados alguns aspectos de sua reprodução e discutidas possíveis relações de causalidade entre a estratégia adotada e a situação ambiental. Os exemplares estudados são provenientes do trecho superior do rio Ubatiba. As coletas foram realizadas mensalmente, por pesca elétrica, entre out./94 e set./95. Foram registradas algumas diferenças nas estratégias de machos e fêmeas. As fêmeas foram significativamente ( $\mathrm{p}<$ $0,05)$ maiores que os machos; a relação peso/comprimento é significativamente diferente $(p<0,05)$ 
entre os sexos; e na primeira maturação também há diferenças entre os sexos. O investimento reprodutivo é alto para ambos os sexos, mas levemente superior para os machos, sendo o Índice Gônado Somático máximo de fêmeas e machos de 40,97\% e 44,90\%, respectivamente. Exemplares reprodutivos foram freqüentes ao longo de todo o ano, sugerindo que a reprodução da população é contínua. A fecundidade variou de 1.342 a 5.535 ovócitos para fêmeas maduras de 4,4 a 7,0 cm, respectivamente, sendo produzidos 1.105 ovócitos por grama de peixe. Sugerimos que as diferenças na estratégia reprodutiva de machos e fêmeas determinam o padrão observado na estrutura de tamanho, sendo a ausência de machos nas maiores classes de SL conseqüência da precocidade da 1a maturação e/ou do alto investimento reprodutivo. A relação entre a reprodução contínua da população e as condições ambientais poderiam ser explicadas como uma adaptação para maximizar a sobrevivência de jovens, isto é, garantir a manutenção da espécie em um ambiente imprevisível.

Palavras-chave: Characidiinae, riacho costeiro, biologia reprodutiva.

\section{INTRODUCTION}

The Ubatiba river composes a small coastal fluvial system of the Brazilian East Basin in the State of Rio de Janeiro. It flows through deforested meadows for agricultural practices and for cattle ranching, though patches of pristine Mata Atlântica forest which are still common on the slopes of the surrounding rocky hills.

A total of twenty-two fish species make up the Ubatiba river ichthyofauna (Costa, 1984; Mazzoni \& Lobón-Cerviá, 2000). Some studies on life history strategies of fish species are available (e.g., Menezes \& Caramaschi, 1994; Soares-Porto, 1991; Aranha \& Caramaschi, 1999; Mazzoni \& Petito, 1999); nonetheless, a full knowledge of reproductive aspects of the Ubatiba river fishes, is far from complete.

Characidium sp.n. is restricted to the upper Ubatiba on rocky and gravel substrata and riffles (Mazzoni, 1998). It is the most abundant species from the upper Ubatiba River where Mazzoni \& Lobón-Cerviá (2000) registered mean densities of 2686 and 2047 ind.ha $^{-1}$. It is a Characidiinae species under description as some other Characidium species in the coastal streams from Southeast Brazil (Paulo Buckup personal communication). In order to allow the recognition of the species used in the present work, some specimens were deposited in the ichthyological collection of Museu Nacional do Rio de Janeiro (MNRJ 22002).

The main purpose of this work is to describe male and female reproductive strategies, as well as discuss causal relationships between the adopted strategies and environmental characteristics. So, the traits analysed include size of first reproduction, fecundity, sex ratio, size of the gametes, spawning type and reproductive season.

\section{MATERIAL AND METHODS}

\section{Study area}

The Ubatiba fluvial system $\left(22^{\circ} 60^{\prime} \mathrm{S}\right.$ and $\left.42^{\circ} 48^{\prime} \mathrm{W}\right)$ is a typical small Serra do Mar basin ( 16 $\mathrm{km}$ long, $42 \mathrm{~km}^{2}$ ) located $70 \mathrm{~km}$ north from Rio de Janeiro city. It composes, together with its tributaries (Silvado, Caboclo, Fundo, Itapeteiú and Ludigério rivers) a small fluvial system whose water level is solely regulated by rain fall $\left(\sim 1500 \mathrm{~mm} \mathrm{yr}^{-1}\right)$. Local hydric regime indicates an absence of seasonality (Mazzoni, 1998) and the main physical characteristic is the sudden spates that stress local habitats and, probably, populations (Fig. 1).

\section{Sampling procedure and data analysis}

Fishes were electrofished (1000 W, 2-3 A) in the upper Ubatiba system, between October/94 and September/95, through monthly sampling (see more detailed information about sampling methodology in Mazzoni et al., 2000a).

Sampled fishes were conditioned in ice for transportation, processed in the laboratory and the following data obtained: (i) standard length (SL) to the nearest $0.1 \mathrm{~mm}$ (ii) total weight (WT) to the nearest $0.01 \mathrm{~g}$ (iii) sex (iv) gonadal weight (WG) to the nearest $0.01 \mathrm{~g}$. Prior to preservation the ovaries/testis were classified in a macroscopic scale of gonadal development according to vascular irrigation as well as on relative occupation in the abdominal cavity, for both sexes; for females size and colour of oocytes was also registered and, for males sperm liberation when pressing the abdomen. 


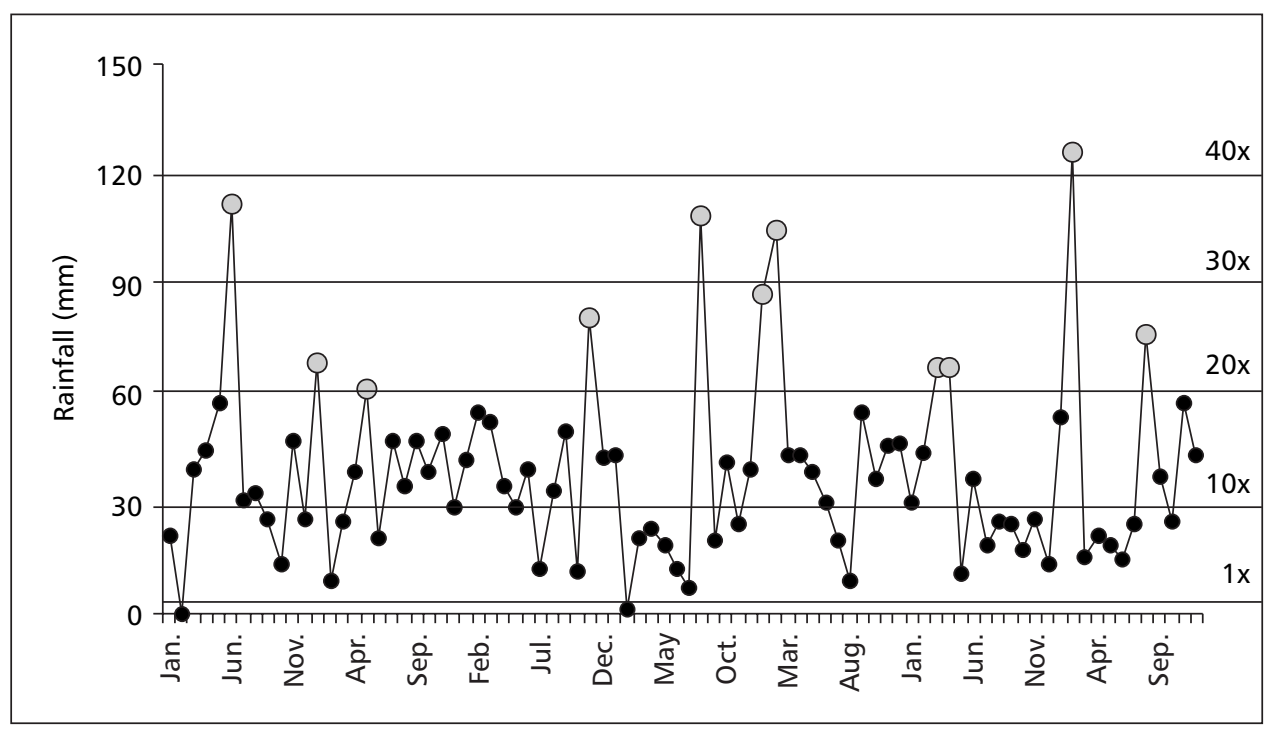

Fig. 1 - Historical series (1989-1994) of temporal variation of monthly mean values of daily rainfall at Maricá region, RJ. Numbers in the right side means the numerical increment in the river water volume and gray spots indicate intermediate and hard disturbs. Data obtained at $6^{\circ}$ Distrito do Instituto Nacional de Meteorologia (INMET, RJ).

According to these characteristics the following classification was considered: females - immature, mature 1, mature 2, ripe and spawned; and males - immature, mature 1 , mature 2 , ripe and spent. Thereafter, ovaries were fixed in modified Gilson's fluid (Vazzoler, 1981) for oocytes measurements and counts.

Ovaries preserved in Gilson's fluid were stored for two weeks and shaken periodically to promote oocyte release. Oocytes were then cleaned by subsequent alcohol change and removal of the ovarian walls, and stored in a $70^{\circ}$ GL alcohol solution. Fecundity (Bagenal \& Braum, 1971) was determined after counting all vitellogenic oocytes from 25 ripe ovaries and correlated to SL and WT. Spawning type was evaluated according to the distribution of oocytes diameter (measured on subsamples of $10 \mathrm{ml}$ under a stereomicroscope-x50) from dissociated ovaries in different maturation stages (mature 1, mature 2 , ripe and spawned).

Standard length structure analysis was determined from the number of individuals in different size classes. Length/weight relationship was established from the LN transformed data of SL and WT, throughout the Minimum Square Method. The size of first maturation $\left(\mathrm{SL}_{50}\right)$ was determined according to the methodology presented in Vazzoler (1981). All the previously mentioned analysis were done for males and females separately.

Sex ratio was determined for the whole sample and the bias in the individual proportion of each sex were tested by the chi-square test $\left(\mathrm{X}^{2}\right)$. Temporal distribution of ovarian/testis maturation stages was used to determine reproductive season; for this, maturation stages were rearranged as follows: immature - young fishes without developed gonads and SL equal or under $\mathrm{SL}_{50}$; nonreproductive - adult fishes, $\mathrm{SL}$ over $\mathrm{SL}_{50}$, in mature, mature 1 and 2 and recovering gonads; and reproductive - adult fishes, $\mathrm{SL}$ over $\mathrm{SL}_{50}$, ripe and spawned/spent gonads. Temporal variation of female Gonadossomatic Index (GSI = WG/WT * 100) was used as complementary information for the determination of reproductive season.

\section{RESULTS}

A total of 165 specimens were analysed, being 51 females and 114 males; sex ratio presented significant differences from the expected $1: 1$ $\left(\mathrm{X}^{2}=24.96: \mathrm{p}<0.001\right)$, so the 2.2:1 (male:female) proportion, was determined. 


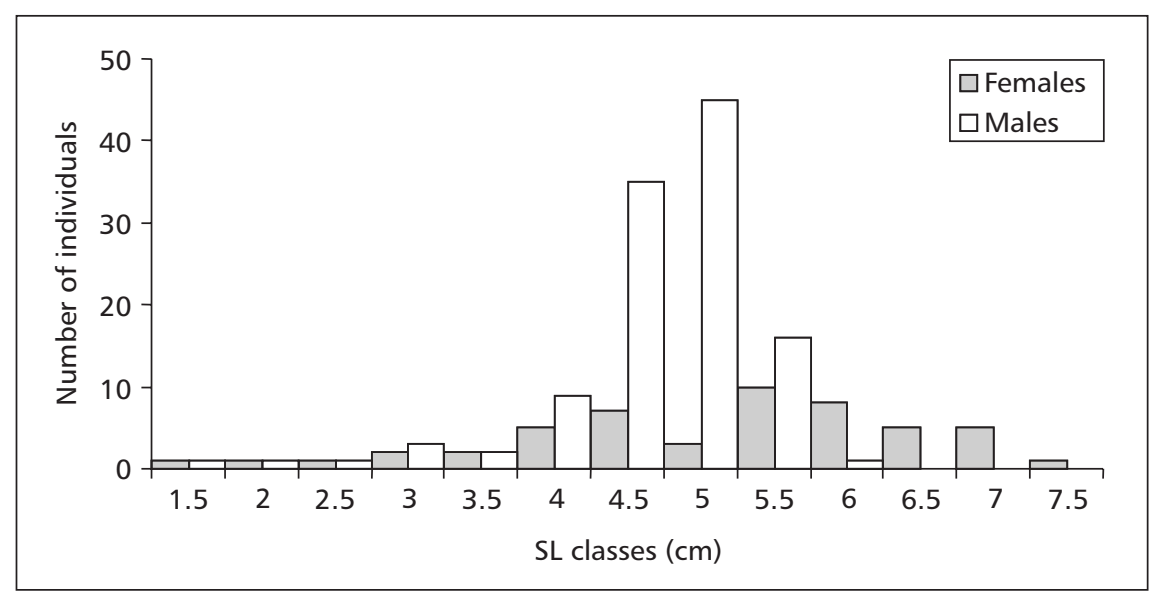

Fig. 2 - Standard length distribution of males and females Characidium sp.n. from the Ubatiba fluvial system, Maricá, RJ. SL 50 means standard length at sexual maturity.

Maximum standard length was $7.5 \mathrm{~cm}$ and 6.0 $\mathrm{cm}$ for females and males, respectively (Fig. 2). Mean size between sexes were significantly different $(\mathrm{t}=4.62 ; \mathrm{p}<0.01 ; \mathrm{DF}=152)$, being $5.3 \mathrm{~cm}$ and $4.7 \mathrm{~cm}$ for females and males, respectively.

Sexual dimorphism was detected for SL/WT relationship $\left(\mathrm{t}_{\text {calc }}=2.08>\mathrm{t}_{\text {estim }}=1.99 ; \mathrm{p}<0.02\right.$; $\mathrm{DF}=134$ ), thus, two different equations explain the SL $\times$ WT relationship: $\mathrm{WT}=-4.24+3.11 \mathrm{SL} ; \mathrm{r}^{2}=0.82$; $\mathrm{p}<0.01$ for females and $\mathrm{WT}=-3.51+2.59 \mathrm{SL}$; $r^{2}=0.73 ; p<0.01$ for males. Size of first maturation $\left(\mathrm{SL}_{50}\right)$ differed between sexes being $4.0 \mathrm{~cm}$ for females and $3.0 \mathrm{~cm}$ for males (Fig. 3a, b).

Temporal variation of maturation stages shows that reproductive specimens occur during the whole annual cycle with a reproductive peak between January and June; this is corroborated by the GSI values, indicating reproductive specimens (GSI > 5) all over the year (Fig. 4). GSI values of males and females, in different maturation stages, indicate higher reproductive effort among males (Table 1).

Oocyte diameter distribution suggests that the species have total spawning (Fig. 5). Mature 1 stage presents one oocyte mode with a diameter of $0.3 \mathrm{~mm}$, which reaches $0.6 \mathrm{~mm}$ in Mature II and $0.8 \mathrm{~mm}$ in Ripe gonads.

Fecundity (F) varied from 1342 to 5535 for ripe females of 4.4 to $7.0 \mathrm{~cm}$, respectively, correlation between SL and $\mathrm{F}$ followed a linear relationship $\left(\mathrm{F}=-11.82+1.38 \mathrm{SL} ; \mathrm{r}^{2}=0.43 ; \mathrm{n}=12 ; \mathrm{p}=0.02\right)$. Considering that the mean number of oocytes per grams of weight is independent of fish size the mean number of oocytes per grams of weight as 1105 oocytes (standard deviation $=225$ oocytes) per grams of weight was calculated. Ripe oocytes have a mean diameter of $0.75 \mu \mathrm{m}$ (range $=0.7$ to $0.85 \mu \mathrm{m}$ ).

\section{DISCUSSION}

A set of traits that draw the reproductive strategy of Characidium from the Ubatiba river, suggests a high reproductive effort, for both males and females, that is reflected in: (i) early onset of sexual maturation, (iii) high values of GSI, (iv) prolonged reproductive season and (v) high fecundity. Therefore, according to life-history theory (sensu Stearns \& Crandal, 1984) the trade off between all of these characters and optimum reproductive life span assure the maintenance of the species that, probably, balance high losses caused by environmental constraints, with high reproductive effort. Our results indicate that Characidium from the Ubatiba river reproduces throughout the year. This information is in agreement with that found for other fish species in the same river (e.g., Menezes \& Caramaschi, 1994; Mazzoni \& Iglesias, 1996; Mazzoni \& Petito, 1999) as well as for other tropical fish species (e.g., Mazzoni \& Caramaschi, 1995; Mazzoni \& Caramaschi, 1997; Mazzoni et al., 2000b). Extended reproductive season has been treated as an adaptive response to environmental constraints that prevail in streams (Garutti, 1983, 1988). 

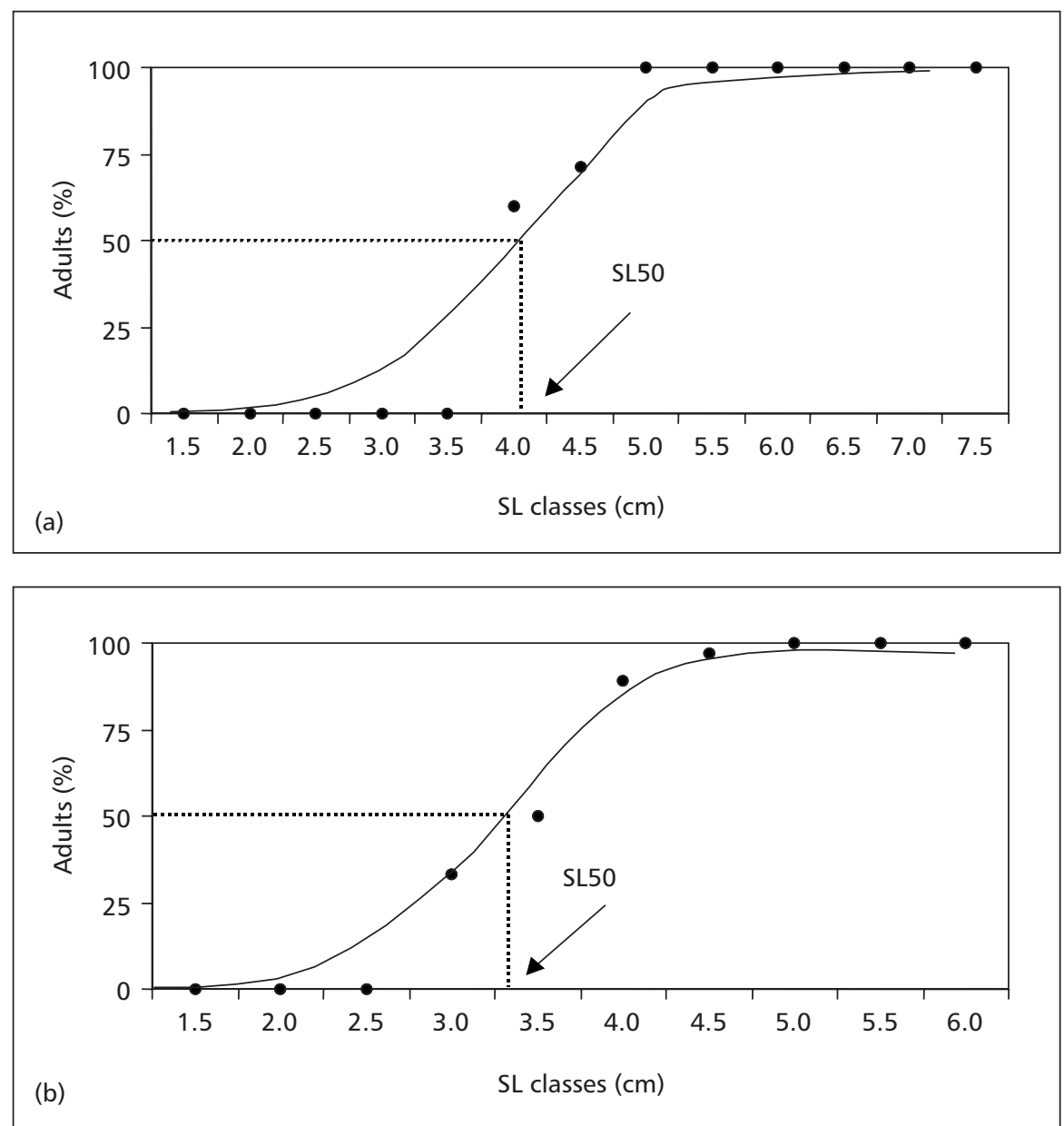

Fig. 3 - Length-frequency distribution of females (a) and males (b) adult Characidium sp.n. from the Ubatiba fluvial system, Maricá, RJ.

TABLE 1

Values of Gonadosomatic Index (GSI) of male and female Characidium sp.n., in different maturation stages.

\begin{tabular}{|l|c|c|c|c|c|c|}
\hline \multirow{2}{*}{\multicolumn{1}{c|}{ Stage }} & \multicolumn{3}{|c|}{ Females } & \multicolumn{3}{c|}{ Males } \\
\cline { 2 - 7 } & Mean & SD & Max & Mean & SD & Max \\
\hline Imature & 0.51 & 0.18 & 0.86 & 0.64 & 0.32 & 0.97 \\
\hline Mature 1 & 2.35 & 1.55 & 5.34 & 2.04 & 0.70 & 2.97 \\
\hline Mature 2 & 7.68 & 1.06 & 8.95 & 4.39 & 1.24 & 8.64 \\
\hline Ripe & 22.61 & 8.49 & 40.97 & 26.09 & 5.72 & 44.90 \\
\hline
\end{tabular}




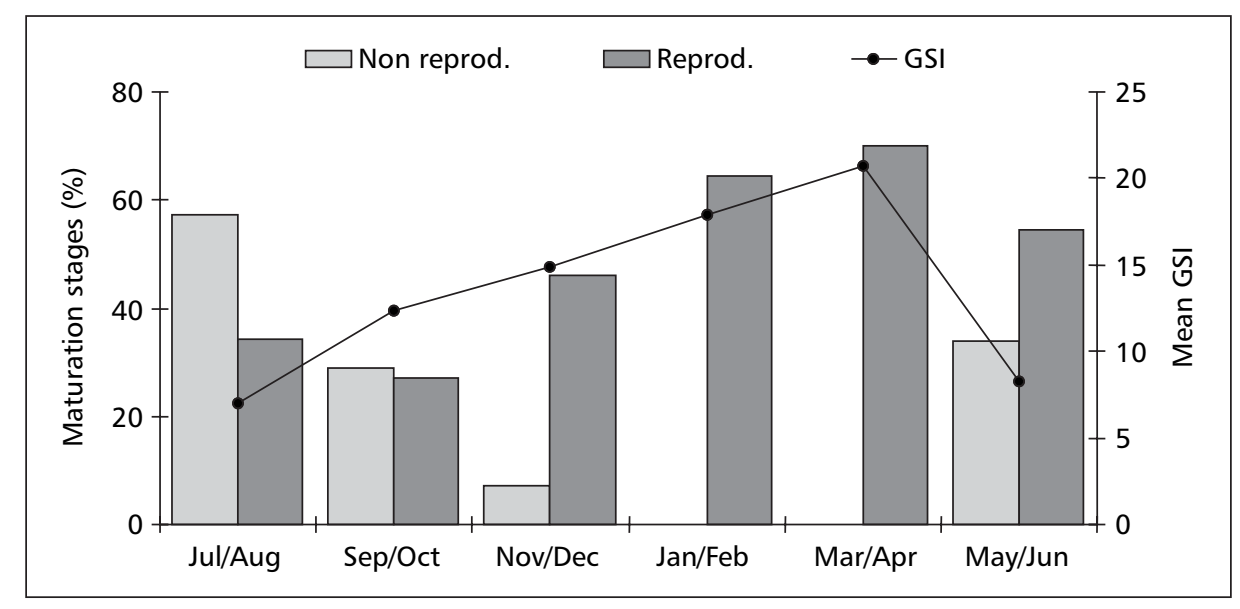

Fig. 4 - Temporal variation in the gonadal stages frequency and Gonadosomatic Index (GSI) of Characidium sp.n. from the Ubatiba fluvial system, Maricá, RJ.

Corroborating such proposition, Matthews (1998) argues that environmental constraints may set limits on life-history traits that are successful or enhance fitness of a species in a particular situation; in the case of Ubatiba river, a prolonged reproductive season may be explained as an important strategy to assure new born supervivency in a stochastic environment, in the same manner as proposed by Garutti $(1983,1988)$.

Nevertheless, it is well known that latitudinal differences exist in life-history traits of fish species. Slower growing, later onset of reproduction and brief spawning season are common among fishes from temperate zones (e.g., Wootton, 1984; Knight \& Ross, 1992; Heins \& Machado, 1993); but, it was also registered that tropical fish populations, despite living in rivers, streams or lagoons (between $22^{\circ} \mathrm{S}$ and $20^{\circ} \mathrm{S}$ ) usually have an extended breeding season (Mazzoni \& Caramaschi, 1995; Mazzoni \& Caramaschi, 1997) due to available resources all year long (i.e., large photoperiod, abundant food supply, high temperatures all over the annual cycle).

The total spawning strategy presented by female Characidium from the Ubatiba river suggests a contradiction between time and type of spawning. Nonetheless, it has been noticed that many species from the studied river have total spawning type and associated rapid and continuous oocyte recruitment and development (R. Mazzoni unpublished data); such a strategy plus a population reproductive asynchrony could explain the reproductive pattern shown in the present study.
Some results point to life history differences between females and males, and suggest higher reproductive investment between the latter's. Males are smaller than females, attain sexual maturity at lower sizes, presents higher values of GSI and length/weight relationship is significantly different (heavier females). Body size differences between sexes were referred by Nikolsky (1963) as the most frequent form of fish dimorphism and, larger size among females has been suggested to be an evolutionary advantage in order to produce, potentially, more and larger offspring. The positive correlation between SL and fecundity, found in our study, supports this proposition, but did not explain all the differences registered for the reproductive strategy of both sexes.

Higher values of GSI and the onset of sexual maturation at lower sizes between males are important points that suggest high reproductive effort. It has been suggested that early maturity can be related to an adaptive behavior that compensates the high juvenile losses, as a consequence of the stressed climate that prevails in the Ubatiba river system (Mazzoni \& Petito, 1999). The imbalanced number of male in the higher SL may be claimed as a consequence of differential mortality and/or growth rates caused by the differences on the reproductive investment between sexes.

Evidences for mortality and different growth rates as a cost of reproduction are supported by some studies (e.g., Goulart \& Verani, 1992; Mazzoni \& Caramaschi, 1995) and could explain the SL structure presented by the male population. 


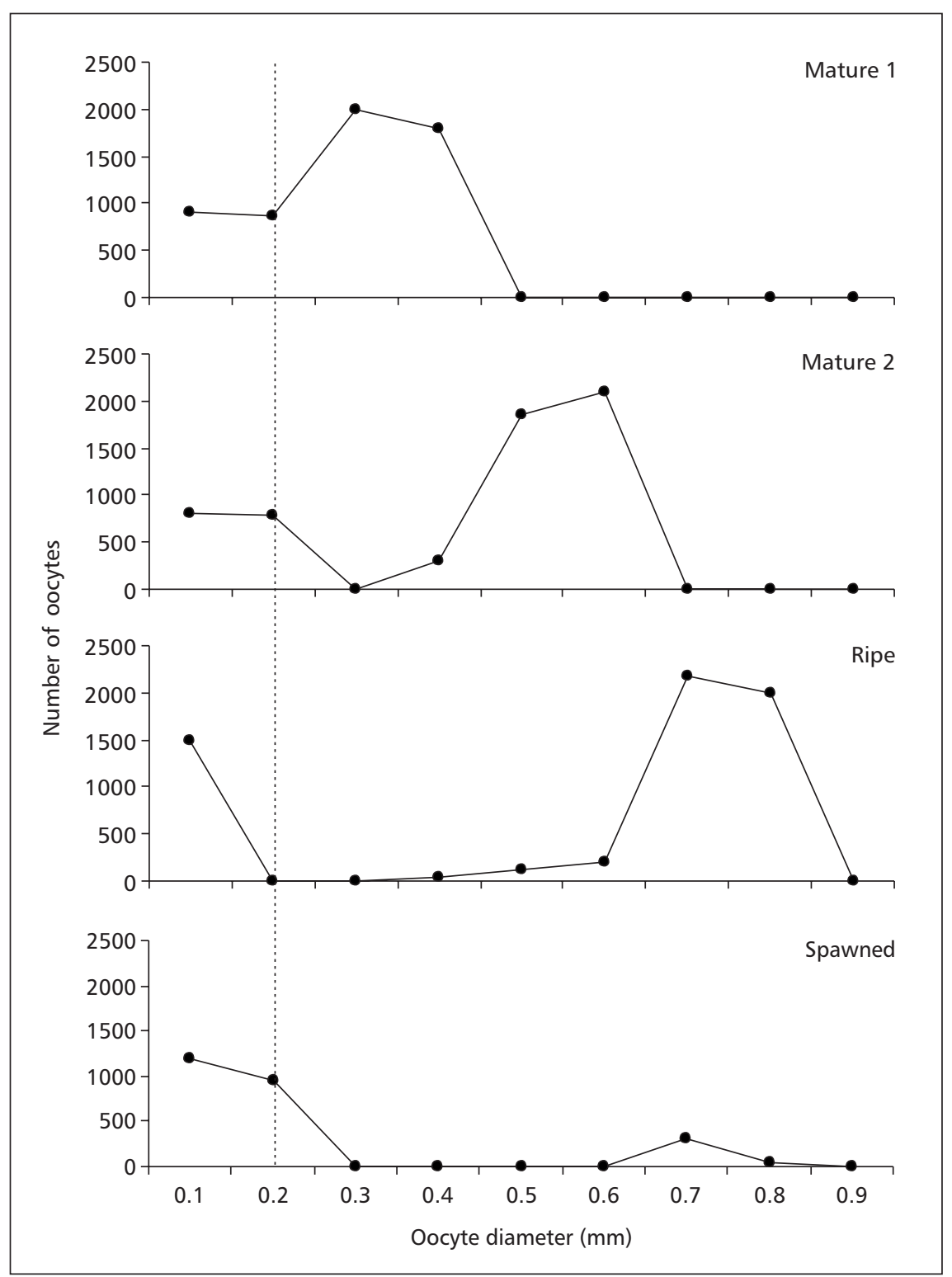

Fig. 5 - Oocyte size distribution of ovaries of Characidium sp.n. in different maturation stages. Oocytes to the left side of doted line represent the stock cells.

Thus, mortality and slow growth arising from heavy investment in early reproduction should counterbalance the early reproductive advantages to generate an optimal size and time of maturity (Rochet et al., 2000); the resolution of this potential conflict should be a pattern of allocation that maximises the reproductive lifetime under prevailing environmental conditions. It is important to mention that no references, concerning reproductive strategy of Characidium species, were found in the literature, in order to allow for comparisons between populations.

Nonetheless, as quoted above, a high reproductive effort among stream dwelling fishes, specially that from the Ubatiba river, were demonstrated elsewhere and, supports the idea that the studied population is under an important environmental pressure that delineate its life history strategy. 
Finally, Characidium reproductive strategy could be considered as an opportunistic strategy (sensu Winemiller \& Rose, 1992). Although this was not tested in the present study, we suggest that the unexpected climatic conditions, especially the stochastic spates plus local climate (low latitudes), could probably be the main determinant of such life-history traits. Part of such proposition has already been done for other fish species from the Ubatiba river (i.e., Menezes \& Caramaschi, 1994; Mazzoni \& Petito, 1999) and corroborates the idea that most of the species from the Ubatiba fluvial system adopt similar reproductive strategies in order to maintain viable populations.

Acknowledgments - We thank the members of the Fish Ecology Laboratories from the Universidade do Estado do Rio de Janeiro and Universidade Federal do Rio de Janeiro for helping in the field work. Ricardo Iglesias Rios for the valuable suggestions on the manuscript. To Chiara Mazzoni for the English revision. This study had financial support from CNPq/Projeto Integrado - 521597/95-1 and FAPERJ/ APQ1 - E-26/170.591/95.

\section{REFERENCES}

ARANHA, J. M. \& CARAMASCHI, E. P., 1999, Estrutura populacional, aspectos da reprodução e alimentação dos Cyprinodontiformes (Osteichthyes) de um riacho do Sudeste do Brasil. Revista Brasileira de Zoologia, 16: 637-651.

BAGENAL, T. B. \& BRAUM, E., 1971, Eggs and early life history. In: W. E. Ricker (ed.), Methods for assessment of fish production in fresh waters. Blackwell Scientific Publications, IBP n. 3, pp. 166-198.

COSTA, W. J. E. M., 1984, Peixes fluviais do sistema lagunar de Maricá, Rio de Janeiro, Brasil. Atlântica, Rio Grande, 7: $65-72$.

GARUTTI, V., 1983, Distribuição longitudinal da ictiofauna do córrego Barra Funda, bacia do Paraná. Dissertação de Mestrado, Universidade de São Paulo, 172p.

GARUTTI, V., 1988, Distribuição longitudinal da ictiofauna em um córrego da região noroeste do Estado de São Paulo, bacia do rio Paraná. Rev. Brasil. Biol., 48(4): 747-759.

GOULART, E. \& VERANI, J. R., 1992, Idade e crescimento do cascudo Hypostomus commersonii Valenciennes, 1840 (Osteichthyes, Loricariidae) na represa Capivarí-Cachoeira, Paraná, Brasil. Rev. Unimar, 14: 1-17.

HEINS, D. C. \& MACHADO, M. D., 1993, Spawning season, clutch characteristics, sexual dimorphism and sex ratio in the redfin darter Etheostoma whipplei. Am. Midl. Nat., 129: 161-171.

KNIGHT, J. G. \& ROSS, S. T., 1992, Reproduction, age and growth of the bayou darter Etheostoma rubrum (Pisces, Percidae): an endemic of Bayou Pierre. Am. Midl. Nat., 127: 91-105.

MATTHEWS, W. J., 1998, Patterns in freshwater fish ecology. Chapman \& Hall, 756p.
MAZZONI, R., 1998. Estrutura das comunidades e produção de peixes de um sistema fluvial costeiro de Mata Atlântica, Rio de Janeiro. Tese de Doutorado, PPGERN, UFSCar, 100p

MAZZONI, R. \& CARAMASCHI, E. P., 1995, Size structure, sex ratio and onset of sexual maturity of two species of Hypostomus Lacépède (Osteichthyes, Loricariidae). Jour. Fish Biol., 47: 841-849.

MAZZONI, R. \& IGLESIAS, R., 1996, Estabilidade ambiental e estrutura de tamanho de populações de Geophagus brasiliensis (Osteichthyes, Cichlidae). In: Resumos do VIII Seminário Regional de Ecologia, UFSCar.

MAZZONI, R. \& CARAMASCHI, E. P., 1997, Observations on the reproductive biology of female Hypostomus luetkeni Lacépède 1803. Ecol. Freshw. Fish, 6: 53-56

MAZZONI, R. \& PETITO, J. T., 1999, Reproductive biology of a Tetragonopterinae (Osteichthyes, Characidae) of the Ubatiba fluvial system, Maricá - RJ. Brazil. Arch. Biol. Technol., 42(4): 455-461.

MAZZONI, R., FENERICH-VERANI, N. \& CARAMASCHI, E. P., 2000a, Electrofishing as a sampling technique for coastal stream fish populations in the Southeast of Brazil. Rev. Brasil. Biol., 60: 205-216.

MAZZONI, R., PETITO, J. \& MIRANDA, J. C., 2000b, Reproductive biology of Genidens genidens, a catfish from the Maricá Lagoon - RJ. Ciência e Cultura, 52(3): 121-126.

MAZZONI, R. \& LOBÓN-CERVIÁ, J., 2000, Longitudinal structure, density and production rates of a Neotropical stream fish assemblage: the river Ubatiba in the Serra do Mar (South-East Brazil). Ecography, 23: 588-602.

MENEZES, M. S. \& CARAMASCHI, E. P., 1994, Características reprodutivas de Hypostomus gr punctatus no rio Ubatiba, Maricá - RJ (Osteichthyes, Siluriformes). Rev. Brasil. Biol., 54: 503-513.

NIKOLSKY, G. V., 1963, The ecology of fishes. Acad. Press. ROCHET, M. J., CORNILlON, P. A., SABATIER, R. \& PONTIER, D., 2000, Comparative analysis of phylogenetic and fishing effects in life history patterns of teleost fishes. Oikos, 91: 255-270.

SOARES-PORTO, L. M., 1991, Distribuição longitudinal, dieta alimentar e ciclo reprodutivo de Pimelodella lateristriga (Osteichthyes, Siluroidei) no rio Ubatiba Maricá, Rio de Janeiro. Dissertação de Mestrado, Museu Nacional do Rio de Janeiro, UFRJ, 156p.

STEARNS, S. C. \& CRANDALL, R. E., 1984, Plasticity for age and size at sexual maturity: a life-history response to unavoidable stress. In: G. W. Potts \& R. J. Wootton (eds.), Fish reproduction: strategies and tactics. Academic Press, London, pp. 13-34.

WINEMILLER, K. O. \& ROSE, K. A., 1992, Patterns of lifehistory diversification in North American fishes: implications for population regulation. Can. J. Fish. Aquat. Sci., 49: 2196-2216.

WOOTTON, R. J., 1984, Introduction: tactics and strategies in fish reproduction. In: G. W. Potts \& R. J. Wootton (eds.), Fish Reproduction: strategies and tactics. Academic Press, London, pp. 1-12.

VAZZOLLER, A. E. A. de M., 1981, Manual e métodos para estudos biológicos de populações de peixes. Reprodução e crescimento. CNPq/Programa Nacional de Zoologia, Brasília. 